\title{
POLITICAL INSTABILITY IN THE COUNTRIES OF NORTH AFRICA AND ITS IMPACT ON THE TRANSPORT OF ENERGY MATERIALS
}

\author{
by Józef Zawadzki
}

\section{INTRODUCTION}

The events that took place in Tunisia in early 2011, proved to be very important for the whole international environment. The northern part of Africa is significant for the Western countries for natural resources which are available there for these reasons, stable and politically predictable, situation in the countries situated there is a strategically important element of a global security system.

Tunisia since mid December 2010 has witnessed riots of young people throughout the country who, in the desperate acts of the self burning claimed democracy in their country, reduction of unemployment (13\%), improving the living conditions and prospects for a better tomorrow for young people. "Jasmine Revolution"1, the name given by the French journal Le Monde to the riots, led to the overthrowing of President Ben Ali, after 23 years of rule and his escape to Saudi Arabia. The revolution

1 Jaśminowa Rewolucja, http://zwierciadlo.pl/artykul/jasminowa-rewolucja, [30.01. 2011]. 
however spread to other, more strategic, from the Western States point of view countries, namely, Egypt, Algeria and Yemen and it is likely to move on to Libya as well.

The Tunisian President escaping to Saudi Arabia, has allowed for the creation of a new Government and the attempts of democratisation in Tunisia. Events in Egypt was were not so optimistic in the beginning as in Tunisia. The demand of the resignation of the current President Hosni Mubarak was not fulfilled but desperate Egyptians continued their fight, referred to in the media as 'silicon chip Revolution'2. Whether the revolution will be a peaceful transition to democracy in the 'Islamic way' or can it be the curse of the Western world, due to the implications on the economies of these countries? These are the questions asked by politicians while waiting for further development of events.

It is important to have a better knowledge of the countries in which the riots took place in the context of the transport of energy products and materials, which currently form the basis of every developed economy in the world.

\section{POLITICAL SYSTEM OF EGYPT}

Egypt is located in North-Eastern Africa across the Mediterranean Sea, between Libya, Israel and the Gaza Strip. The total length of the land border is $2689 \mathrm{~km}$. Adjacent to the Gaza Strip (11 km), Israel $(255 \mathrm{~km})$, Libya $(150 \mathrm{~km})$, Sudan $(1273 \mathrm{~km})$. The length of the coastline is $450 \mathrm{~km}$, it obtained its independence from Great Britain on 28 February 1922.

The total area of Egypt is $1001450 \mathrm{~km}^{2}$. In 2003, the population was 74.7 million, the majority of the population in Egypt are Muslims (Sunni Islam dominate) $94 \%$, and the Coptic Christians with the others make 6\%. The most important cities are: Cairo, Alexandria, Luxor, Port Said, Sharm el Sheikh, and Suez. The area of the country is administratively divided

\footnotetext{
2 It is connected with the way protesters communicated with each other. They used the Internet to inform the society of time and place of meetings.
} 
into 29 governorates (muhafazat). Each province has a Governor representing the President of the Republic.

Egypt is a Republic and has a multi-party political system. In accordance with the Constitution of 1980 people exercise all the authority of law, sovereignty is the basis of governance, and the Egyptian people are part of the Arabian nation. At the head of the Executive there is the President of the Republic which is a legitimate representative of Egypt in times of war and peace. The President must be Egyptian, born of Egyptian parents who is at least 40 years old, have full political and civil rights and his single-candidate selection is done in two stages:

- the President shall be appointed by the legislative body (the People's Assembly);

- candidature put forward by the People's Assembly is then subjected to a popular vote in a nationwide referendum.

The Presidential term of office lasts 6 years starting from the notification of the results of the referendum, with the possibility of re election.

The supreme executive and administrative organ of the State is the government, consisting of the Council of Ministers. They are headed by the Prime Minister and he supervises the work of the government. The highest Executive and administrative organ of the Egyptian Republic is the Council of Ministers. The Ministers are all jointly responsible for the general policy of the State before the People's Assembly, and each Minister is responsible for the performance of his Ministry.

The Egyptian Parliament is bicameral in character and consists of the People's Assembly, or Majlis El-Shaab and the Advisory Council or Majlis El-Shourah.

The People's Assembly is the legislative branch of the State consisting of 444 directly elected members and 10 members appointed by the President, who serve for a term of five years. It has the power to approve the general policy, new laws, the budget and the development plans of the government. It also has the authority to undertake investigations and to levy taxes, besides appointing the Presidential candidate and passing a vote of no-confidence in the cabinet.

The Advisory Council with 140 members, out of which 70 members are nominated by the President, is Egypt's consultative council. It offers 
advice and consultation and proposes to the Assembly new laws and regulations ${ }^{3}$.

An important element is the fact that this is the second of the significant pro-Western countries in the Middle East without which the fragile peace of this region can be completely demolished. The economic situation in this country is even more complex than in Tunisia. This is due, among other things, to the poverty of Egyptians. Experts assess that $40 \%$ of the population lives in poverty, lack of respect for human rights and the total lack of prospects for young people. The official unemployment rate in Egypt is about 9,5\% but informally it is said to be $25 \%$, and inflation runs up to $17 \%$ per annum ${ }^{4}$.

The riots that were spreading fast could also reach the tourist destinations and were so severe that international professionals and the leaders of different countries watched them with concern as Egypt is an important place from a strategic point of view. The strongest opposition, which is the Muslim Brotherhood ${ }^{5}$, may not be the best replacement for Mubarak's

3 Political system of Egypt, http://www.123independenceday.com/egypt/politicalsystem.html, [16.02.2011].

4 Egypt Crisis Stirs Concern for World Economy, http://www.cbsnews.com/stories/2011/01/31/business/main7302094.shtml?tag=topnews, [31.01.2011].

5 The Muslim Brotherhood, or al-Ikhwan al-Muslimun, is Egypt's oldest and largest Islamist organisation. Founded by Hassan al-Banna in the 1920s, the group has influenced Islamist movements around the world with its model of political activism combined with Islamic charity work. The movement initially aimed simply to spread Islamic morals and good works, but soon became involved in politics, particularly the fight to rid Egypt of British colonial control and cleanse it of all Western influence. Today, though officially banned and subject to frequent repression, the Ikhwan lead public opposition to the ruling National Democratic Party of President Hosni Mubarak, who was in power since 1981. While the Ikhwan say that they support democratic principles, one of their stated aims is to create a state ruled by Islamic law, or Sharia. Their most famous slogan, used worldwide, is: "Islam is the solution". In 2000, the Ikhwan won 17 seats in the People's Assembly. Five years later, the group achieved its best election result to date, with independent candidates allied to it winning $20 \%$ of the seats. At the beginning of February 2011, the Ikhwan's leadership issued a statement saying: "We demand that this regime is overthrown, and we demand the formation of a national unity government for all the factions." They also attended an unprecedented meeting between the government and opposition. The talks degenerated into a war of words, with the Ikhwan rejecting Vice-President Omar Suleiman's assertion that consensus had been reached, but the 
regime as it can be a dangerous element causing the trigger for a conflict between Egypt and Israel.

Egypt is also an important element of the world transport system of energy materials and therefore riots in this country are of public concern of the entire Western world. Petroleum and oil in general is one of the basic and most important modern energy materials to the economies of the $21^{\text {st }}$ Century and a key element of their continuous and stable operation. Although Egypt is not the main producer of oil $(670000 \mathrm{~b} / \mathrm{p}-$ barrels/day), but more than 3500 oil tankers passes each year through the Suez Canal. In the event of its closure, tankers supplying Europe from the Persian Gulf will have to take nearly $10,000 \mathrm{~km}$ longer route ${ }^{6}$. The increase of crude oil prices would mean the risk in reduction of forecasts of growth both in the US and Europe. In addition, it should be noted that the current situation in North Africa can be defined as a developing one, since the international community cannot guarantee that the circumstances in other countries of the region remain stable. Countries such as Libya and Algeria should be observed carefully. The media inform that previously mentioned Jordan and Yemen are not stable and therefore the revolutionary movement, is the largest in North Africa for 70 years may "distribute" in other States very quickly.

According to Stratford experts, the most pessimistic is a scenario in which the new Government, after the resignation of the current President of Egypt, will be formed by members of the Muslim Brotherhood Islamic group. This organization does not recognize the peace agreements of Camp David and the state of Israeli. The withdrawal from these agreements would be a great impact on the fragile architecture of Middle East security. In the optimistic scenario, with peace in the region, Europe and the US would also have to pay millions of Western funds to help weak countries endangered with revolutions ${ }^{7}$.

invitation was tacit recognition of their wide support and importance to the protest movement. Egypt's Muslim Brotherhood, http://www.bbc.co.uk/news/world-middleeast-12313405, [16.02.2011].

6 The details of the Suez Canal will be given further in the article.

7 J. Bielecki, Światowa gospodarka słono płaci za egipska rewoltę, "Dziennik Gazeta 


\section{POLITICAL SYSTEM OF TUNISIA}

The Arabic States in North Africa, by the Mediterranean Sea. Obtained their independence from France on 20 March 1956. Borders with Algeria $(965 \mathrm{~km})$ and Libya $(459 \mathrm{~km})$. The coastline has a length of more than $1200 \mathrm{~km}$.

The capital of the country is Tunis. Other major cities: Sfax, Gabès, Ariana, Bizerte, Sousse. Total surface: $163600 \mathrm{~km} 2$. In 2003, the population of Tunisia had 9.9 million inhabitants. In the coastal strip it was around $70 \%$ of the total population of the country. In 2003, the city population was $59 \%$. In Tunisia there is a continuous trend of population movements from continental and coastal areas of agricultural land and to the cities. The illiteracy rate in this country is 33\%. Arabs represent $98.2 \%$ of the population, the Berber people (1.2\%), Europeans (mostly French and Italians) is $0.6 \%$. Outside the country (mainly in France) it is more than 1.5 million Tunisians. The State religion is Sunni Islam - 98\%, Christians $1 \%$, Judaism and other $1 \%$. The official language is Arabic, while in commercial dealings the common language is French (in the tourism sector English and German). Tunisia is divided into 24 ,s governorates called Wilaiams ${ }^{8}$.

Tunisia is a constitutional republic, with a president serving as chief of state, prime minister as head of government, a bicameral legislature and a court system influenced by French civil law. Tunisia was formally a democracy with a multi-party system, based on the constitution of 1959.

The 189 members of the Chamber of Deputies are elected by universal suffrage for a five-year term; 37 of them are elected by proportional representation from those parties that fail to win seats under the first-pastthe-post system; only officially recognised parties can contest elections; a 2002 constitutional amendment led to the establishment of an upper house in August 2005, the 126-member Chamber of Advisers.

Prawna”, http://forsal.pl/grafika/482695,58373,swiatowa_gospodarka_slono_placi_za_ egipska_rewolte.html, [31.01.2011].

8 Tunisia - 2011, CIA World Factbook, http://www.theodora.com/wfbcurrent/tunisia/tunisia_geography.html, [12.02.2011]. 
The president, elected by universal suffrage, for a five-year term with no term limit; currently Zine el-Abidine Ben Ali, who seized power in November 1987; Mr Ben Ali won presidential elections in April 2009 .

Tunisia is the most liberal Arabic country, with enhanced rights of women. Women owe this to Habiba Burgiby the first wife of the President, who was French. She convinced her husband to make several major reforms. Abolition of polygamy, the elimination of wearing traditional khust by women, control the divorce by the courts, the admission of women to schools, Parliament, Government and other forms of public life.

Although the importance of that State on the international stage in the context of export or transportation of oil and other fossil fuels is not as large as Egypt or other States in the region, since it only takes 48 place in the ranking of crude oil drilling $(88,000 \mathrm{~b} / \mathrm{d} \text { in } 2009)^{10}$. However, the events in Tunisia, which started with the demonstrations in other States, were some kind of inflammatory spark for the process that has taken almost the entire range of Northern Africa. The return to the country from a political exile of Rashid Ghannuszi, the leader of the Organization of Tunisian Islamist Ennahda (Renaissance), can potentially bring mixed feelings and even fear to Europe that indeed Tunisia will soon become an incubator for radicalisms aiming to accelerate the creation of the Caliphate. The situation is being watched carefully by the international community.

\section{POLITICAL SYSTEM OF ALGERIA}

Algeria officially the People's Democratic Republic of Algeria (also formally referred to as the Democratic and Popular Republic of Algeria) is a country in North Africa. In terms of land area, it is the largest country on the Mediterranean Sea, the largest in the Arab world and African continent after Sudan, and the eleventh-largest country in the world.

9 Tunisia - political structure, http://www.economist.com/node/13349639, [12.02.2011].

10 EIA Country Analysis Brief - Tunisia, http://www.eia.doe.gov/country/country_ energy_data.cfm?fips=TS, [29.01.2011]. 
Algeria is bordered in the northeast by Tunisia $(965 \mathrm{~km})$, in the east by Libya $(982 \mathrm{~km})$, in the west by Morocco $(1559 \mathrm{~km})$, in the southwest by Western Sahara (42 km), Mauritania (463 km), and Mali $(1376 \mathrm{~km})$, in the southeast by Niger $(956 \mathrm{~km})$, and in the north by the Mediterranean Sea costal line of $998 \mathrm{~km}$. Its size is almost 2.400 square kilometres, and it has an estimated population of 35.7 million (2010). The capital of Algeria is Algiers. Algeria is a member of the Arab League, United Nations, African Union, and OPEC ${ }^{11}$. It is also a founding member of the Arab Maghreb Union ${ }^{12}$.

The head of state is the president of Algeria, who is elected for a fiveyear term. The president was formerly limited to two five-year terms but a constitutional amendment passed by the Parliament on November 11, 2008 removed this limitation. Algeria has universal suffrage at 18 years of age. The President is the head of the Council of Ministers and of the High Security Council. He appoints the Prime Minister who is also the head of government. The Prime Minister appoints the Council of Ministers.

The Algerian parliament is bicameral, consisting of a lower chamber, the National People's Assembly (APN), with 380 members; and an upper chamber, the Council Of Nation, with 144 members. The APN is elected every five years.

Under the 1976 constitution (as modified 1979, and amended in 1988, 1989, and 1996) Algeria is a multi-party state. The Ministry of the Interior must approve all parties. To date, Algeria has had more than 40 legal political parties. According to the constitution, no political association may be formed if it is "based on differences in religion, language, race, gender or region."13

Political stability in this country is very important for many European countries especially France and Italy. Algeria contributes in oil production and transportation and has large reserves of these material. More information will be given in future parts of this article.

11 Organization of the Petroleum Exporting Countries

12 Africa: Algeria, CIA World Factbook. Cia.gov., [12.02.2010].

13 BBC NEWS, News.bbc.co.uk. November 12, 2008 [24.11.2008]. 


\section{POLITICAL SYSTEM OF LIBYA}

Libya (officially the Great Socialist People's Libyan Arab Jamahiriya) is a country located in North Africa. Bordering the Mediterranean Sea to the north, Libya lies between Egypt to the east $(1115 \mathrm{~km})$, Sudan to the southeast $(383 \mathrm{~km})$, Chad $(1055 \mathrm{~km})$ and Niger to the south $(354 \mathrm{~km})$, and Algeria $(982 \mathrm{~km})$ and Tunisia $(459 \mathrm{~km})$ to the west ${ }^{14}$.

With an area of almost 1,800,000 square kilometres, Libya is the fourth largest country in Africa by area, and the $17^{\text {th }}$ largest in the world. The capital, Tripoli, is home to 1.7 million of Libya's 6.4 million people. The three traditional parts of the country are Tripolitania, Fezzan, and Cyrenaica.

There are two branches of government in Libya. The "revolutionary sector" comprises Revolutionary Leader Gaddafi, the Revolutionary Committees and the remaining members of the 12-person Revolutionary Command Council, which was established in 1969. The historical revolutionary leadership is not elected and cannot be voted out of office; they are in power by virtue of their involvement in the revolution.

The second sector, the Jamahiriya sector, comprises Local People's Congresses in each of the 1,500 urban wards, 32 Sha'biyat People's Congresses for the regions, and the National General People's Congress. These legislative bodies are represented by corresponding executive bodies (Local People's Committees, Sha'biyat People's Committees and the National General People's Committee/Cabinet).

Every four years, the membership of the Local People's Congresses elects their own leaders and the secretaries for the People's Committees, sometimes after many debates and a critical vote. The leadership of the Local People's Congress represents the local congress at the People's Congress of the next level. The members of the National General People's Congress elect the members of the National General People's Committee (the Cabinet) at their annual meeting ${ }^{15}$.

\footnotetext{
${ }^{14}$ Libya, http://portalwiedzy.onet.pl/77949,,,,libia,haslo.html, [24.01.2011].

15 Human Development Report 2010, United Nations. 2010. [05.11.2010].
} 
Due to its large petroleum and oil reserves and lifting of the United Nation sanctions in 2003 the country contributes to the world oil production and distribution especially to European countries such as Italy, France, Germany. The exact data will be presented further in the paper.

\section{TRANSPORTATION OF OIL IN THE DESTABILIZED REGION}

Considering the situation not only in respect of the supply of energy materials but also the rest of the trading exchange by sea, it can be a contribution to a dramatic jump in oil prices on the stock exchanges, as well as it may result in the breakage or disruption and continuity of supplies of raw material. As mentioned previously, Egypt is not the most important producer of crude oil supplies, but Algeria and Libya's contribution to the import of oil by the countries of Western Europe, the United States, China and Japan is significant.

The Mediterranean Sea for centuries has been playing an important role in the economic system of Europe and also for North America so the security of maritime lanes in this region is a very important element for the success of world economy. The trade routes from North to South and from East to West cross the area of the Mediterranean basin. For this reasons there are several dimensions of maritime traffic in the Mediterranean, which can be considered on three levels:

- As a 'maritime route' that, as such, is one of the world's major trade routes, through which nearly a third of world trade 'passes', from the mouth of the Suez Canal to the Straits of Gibraltar or the Bosporus, from the Atlantic to the Black Sea.

- As a 'crossroads' of continents -European, Asian and Africanwhose trade is growing with globalisation.

- As a 'landlocked sea' through which coastal countries develop their trade.

In this ensemble, there is naturally maritime trade between Mediterranean countries and the rest of the world, but above all, trade takes place between the entire EU and countries of Asia and the Middle East via the 
Mediterranean Sea. The trade between EU Member States and Asia amounted to approximately 210 million tonnes in 2006 and has been rising strongly for the past twenty years or so. It essentially consists of diverse, 'non-bulk' merchandise transported in containers. The containerisation rate for non-bulk traffic is often greater than 80 and even $90 \%$. The Mediterranean offers a route for the exchange of manufactured goods between Europe and Asia, as well as for European supplies in energy products from the Persian Gulf and North African countries. Around 25\% of the trade consists of energy products ${ }^{16}$.

In terms of international shipping traffic, it is estimated that about 220,000 vessels of more than 100 tonnes each cross the Mediterranean annually (EEA, 2006). The Mediterranean Sea is one of the seas with the highest traffic density in the world. More than 300 ports, often located in densely populated areas particularly in Greece and Italy, exist in the region. $20 \%$ of such ports are in the eastern Mediterranean the remaining $80 \%$ in the West and Central Mediterranean. Moreover, the Mediterranean region is also characterized by a significant traffic of vessels passing the Mediterranean Sea without entering any of these ports. Apart from the vessels taking shorter routes on the way to Europe and North America every day there are about 2000 ferries and passenger liners travelling across the Mediterranean. Besides there are about 1500 units of cargo and 2000 units of various types including 300 oil tankers ${ }^{17}$.

The volume of sea-borne trade in the Mediterranean Sea, which represents less than $1 \%$ of the total area covered by the world's oceans, is estimated to be approximately $30 \%$ of the international sea-borne trade volume and about $20-25 \%$ of the world's sea-borne oil traffic, which takes place within or through the Mediterranean Sea (REMPEC).

16 C. Reynaud, The Components of Maritime Transport in the Mediterranean, http:// www.iemed.org/anuari/2009/aarticles/a255.pdf, p. 2-3, [15.01.2010].

17 Maritime transport of goods., http://www.planbleu.org/publications/4p_transport_maritime14_EN.pdf, p. 2-5, [20.10.2010]. 


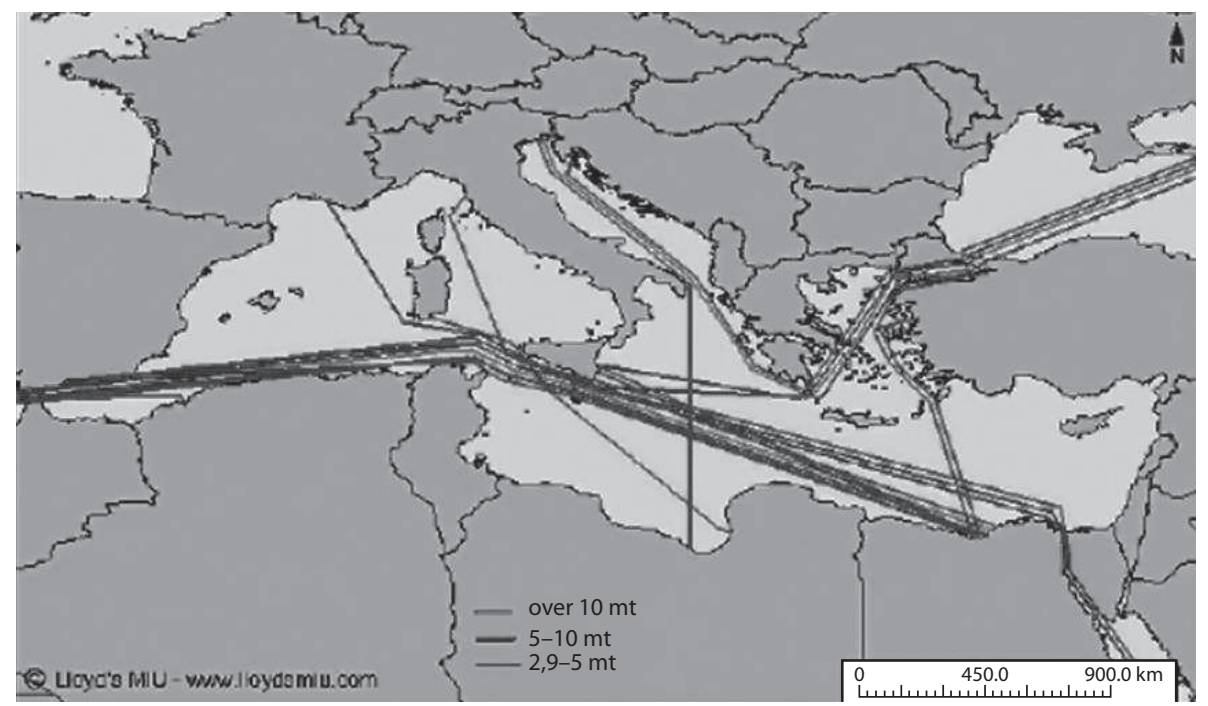

Fig. 1: Crude oil traffic in major Mediterranean ports - 2006, Source: Lloyd's MIU

The Mediterranean Sea is the major route for transportation of crude oil from the oil fields in the Middle East and North Africa, and oil ports in the Black Sea towards the major consumption centres in Europe as well as in North America. In general the main tanker traffic flows in the EastWest direction. The major traffic lanes are:

- Novorossiysk (Russia) to Mediterranean destinations,

- Sidi Kerir (Egypt) to both Mediterranean and North Western Europe destinations through the Straits of Gibraltar,

- The Persian Gulf via Suez Channel through the Mediterranean.

Particularly congested transport corridors are just off the trail of the Gulf of Suez Canal, as well as routes with numerous terminals for the loading of Egypt, Libya and Algeria, where the transport stream of energy materials flows continuously for virtually the whole world. The main transport routes of oil and its products in the region are directly associated with countries of North Africa include:

- Terminal Sidi Kerir (Egypt)-transport to the ports of the Mediterranean Sea (e.g.: Sarroch, Trieste, Augusta, Italy, the Fos in France) and through the Straits of Gibraltar to Northern Europe;

- Fuel terminals in Arzew, Algeria, Skikda, Bajaia; 
- Fuel terminals in Libya Marsa El-Brega, Las Ranuf and Zueitina. In 2004 the transport of oil and petroleum products for the European Union was 670 million tonnes, of which $85 \%$ - 567 million tonnes was crude oil of which $85 \%$ was transported by the shipping routes in the Mediterranean Sea and only the remaining 15\% was transported by pipes.

As experts for logistics, transport, the demand for raw materials and energy predict, the overall movement in the Mediterranean Sea to the year 2025 will grow each year and the level of growth is anticipated at $0.3 \%{ }^{18}$. It should be stressed that all the experts confirm that the transport of energy materials will play an important role in the general increase of goods transported by sea. A stable situation in the coastal countries of the region is necessary to ensure safe transport through the enforcement of e.g. The Law of the Sea. The lack of the possibility to control the waters by weak States or restriction of this control only to a minimum may result in the future of the development of piracy in the area. The example of a massive problem caused by the political weakness and poverty in a state, which the international community faced from the end of 2008, is Somalia. The situation in the countries of the Maghreb a long way from the situation in Somalia today but learning from this experience we should not underestimate the present situation in the described countries.

Due to the region where the riots take place, the most important, of course, has already been mentioned the Suez Canal. To keep short delivery times and reduce transportation costs associated with fuel needed to transport mass stock, owners choose the shortest shipping routes. This is also partly related to the care and protection of the environment through the reduction of shipping lanes and discharge into the atmosphere as little $\mathrm{CO}^{2}$ as possible. The choice of route is particularly important for the transport of energy materials and especially oil and petroleum, if the price of them is to remain at an acceptable level. The change would mean much longer routes of transport and thus a more expensive journey for oil tankers, which would increase significantly the cost of transport and the final price of the product.

\footnotetext{
18 Ibidem.
} 


\section{STRATIGIC REGION OF OIL TRANSPORT - THE SUEZ CANAL AND THE SUMMED PIPELINE}

From the point of view of safety and economics of maritime transport, the Suez Canal, located in the territory of Egypt, is the most important element of global sea lines of communication. The works for the project took place in 1859-1869 as a deep canal for sea-going vessels, linking the Mediterranean to the Red Sea. In the southern part of the route the canal runs through Little Bitter Lake, Great Bitter and Lake Timsah to Port Said. It is $190 \mathrm{~km}$ long and 300 meters wide after modernization in 2010. The canal supports approximately $8 \%$ of the world's shipping traffic with almost 50 vessels travelling through the canal daily. the maximum draught of vessels-11,6 $\mathrm{m}$ (after the modernization of the canal the depth is $22 \mathrm{~m}$ ). the Egyptian government hopes to have widened and deepened the Suez Canal enough to accommodate the passage of very large crude carriers (VLCCs) and ultra large crude carriers (ULCCs) ${ }^{19}$. The average number of vessels travelling this way do not exceed 44 ships a day, while the average time for a ship to travel by the Channel is about 15 hours. Every 10 $\mathrm{km}$ there are lay-bys for passing ships. Thanks to the building of the Suez Canal the navigable route from London to Mumbai has been squeezed around 7.5 thousand kilometres. The canal can accommodate vessels with a deadweight tonnage of 150.000 tonnes at full load, unfortunately it is not wide enough to allow the two-way traffic of ships and therefore, as it was mentioned above, there are the lay-bys for moving units. There were 3,9 million barrels of oil transported a day in 2006, mainly in the direction of Europe, but also to the United States. Each year, 3500 oil tankers passes through the Canal which is about $25 \%$ of all revenue derived from fees paid by the transitions ${ }^{20}$. The Suez Canal is an important trail for shipping around the world and especially for the transport of crude oil. It significantly shortens the route and keeps the price of oil at a certain, acceptable level. It is also important for the transport of other commodities such as

\footnotetext{
19 Suez Canal, Egypt, http://www.eoearth.org/article/Suez_Canal,_Egypt, [23.02.2011].

20 World Oil Transit Chokepoints, http://www.eia.doe.gov/cabs/World_Oil_Transit _Chokepoints/Full.html, [21.12.2011].
} 
iron ore and colour metals, wood, grain, and passengers being itself a tourist attraction because of the way ships move through the Canal. During its nearly 150-year history the Canal was closed to navigation for eight years (see war in June 1967). Officially, the Treaty on the Canal secures freedom using this transition ${ }^{21}$.

The unstable situation in Egypt and especially in big cities, also Suez, makes the oil prices on the commodities market go up. The riots of the population, which requested the resignation of the President and power being taken by the opposition were so strong that experts assess that, it is difficult to predict how the future will develop in this country. If the opposition after elections and taking power, deal in a rational way with many problems, ensuring the continuity of maritime transport by the Suez Canal should be the priority for the new Government, since the revenue from the charges for crossing the Canal are an important element of the budget in Egypt.

The Region of the Middle East is extremely rich in oil so countries such as the United Arab Emirates, Kuwait or Qatar are places of export of oil especially in the direction of strong, technologically developed countries of the world, among which the US and Europe are the most important.

At the same time, this region is due to its history politically unstable, therefore ensuring the safe transport of oil and its products is a very important challenge for the entire international community. As it was mentioned earlier the Suez Canal connecting the Red Sea to the Mediterranean is the shortest trail shipping business in this region which saves time and fuel by the possibility of shortening the journey by about 7,500 kilometres. Unfortunately, the technical capabilities of the canal substantially restrict the volume of oil tanker able to use that route. Data on the oil transportation by the Suez Canal in the past three years will be presented further. Unfortunately, compared to 2008 there was a decrease in the quantity of oil transported by the Suez Canal by almost $50 \%$ and this trend reflected the fall in oil prices in the fourth quarter of 2008 lower limits on oil mining, mainly from the Persian Gulf dictated by OPEC. It

21 P. Roberts, The End of Oil: On the Edge of a Perilous New World, New York 2004, pp. 87-89. 
was also connected with the problem of piracy in the Horn of Africa, which significantly increases the degree of risk to the transport of oil, after successful kidnapping the tanker Sirus Star by the pirates in 2008.

As mentioned previously, the technical possibilities of the channel greatly limit its bandwidth, especially with respect to large units, Egypt decided to solve the problem by building the pipeline SUMED to transport crude oil (Figure 2). This was certainly associated with the growing demand in oil and petroleum, from 2008.

The system allows to empty an oil tanker and pump the oil along the canal in the pipeline system and then reload an oil tanker on the coast of the Mediterranean Sea. The Pipeline going to a Sidi Kerir Terminal, in the Mediterranean Sea has the capacity up to 2.5 million barrels per day. It is owned by Arab Petroleum Pipepline co. The corporation is a joint venture of Egyptian General Petrolium Corporation (EGPC) having 50\% of the shares, the Saudi Arabian Oil Corporation Aramco-15\% of the shares, International Petroleum Investment Co. IPIC (ABU DHABI)-15\% of the shares, the three companies (including tankers of 15\%) and the Quatar Petrpleum (QGPC)-5\% of the shares.



Fig. 2. Sumed pipelines, source: http://www.google. pl/imgres?imgurl=http://3.bp.blogspot.com/_ o2H52OH-, [21.02.2011]. 
The pipeline started working in January 1977 and it is an alternative way of oil supplies from the direction of the Middle East ${ }^{22}$.

Sidi Kerir fuel terminal is on the North coast of Africa, $27 \mathrm{~km}$ west of Alexandria is served by the Arab Petroleum Pipelines CO. company SUMED. The Terminal has a strategic position, and together with the Terminal Ain Sukhna, which is located on the West coast of the Red Sea is an important element in the crude oil transport corridor in the region. It is worth stressing that, through the Suez Canal, or with the help of the SUMED pipeline $80 \%$ of oil and petroleum is transported from the Persian Gulf to Europe ${ }^{23}$. Oil loaded in Sidi Kerir Terminal is most often transported to the following places:

- Leghorn - Italy;

- Augusta - USA;

- Rotterdam - The Netherlands.

The world crisis, which began at the end of 2008 was reflected also in the quantities of crude oil transported by SUMED. According to the APEX (Atlas of the Petroleum Exploration Worldwide), the stream of oil in 2009 amounted to $1.1 \mathrm{mb} / \mathrm{d}$ as compared to the year $2008(2,1 \mathrm{mb} / \mathrm{d})$ was a significant decrease. In conclusion, the available data on the transport of crude oil and petroleum products from the direction of the Gulf via Suez Canal and SUMED pipeline on the Mediterranean Sea developed as follows in the different years:

Table 1. Transport of oil in Egypt, own analysis on the basis of: Suez Canal Authorities, http://www.suezcanal.gov.eg/Files/Publications/32.pdf, Egypt Energy Data, Statistics and Analysis, http:// www.eia.doe.gov/cabs/Egypt/pdf.pdf, Retrieved 22.01.2011.

\begin{tabular}{|l|c|c|c|}
\hline & 2007 & 2008 & 2009 \\
\hline Suez Canal & $965,000 \mathrm{~b} / \mathrm{d}$ & $1,16 \mathrm{mln} \mathrm{b} / \mathrm{d}$ & $585,000 \mathrm{~b} / \mathrm{d}$ \\
\hline SUMED & $2,2 \mathrm{mln} \mathrm{b} / \mathrm{d}$ & $2,1 \mathrm{mln} \mathrm{b} / \mathrm{d}$ & $1,1 \mathrm{mln} \mathrm{b} / \mathrm{d}$ \\
\hline Total & $3,165 \mathrm{mln} \mathrm{b} / \mathrm{d}$ & $3,26 \mathrm{mln} \mathrm{b} / \mathrm{d}$ & $1,685 \mathrm{mln} \mathrm{b} / \mathrm{d}$ \\
\hline
\end{tabular}

22 SUMED Electronic brochure, http://www.sumed.org/docs/Web/index.html, p. 34, [17.01.2011].

23 Egypt Energy Data, Statistics and Analysis, http://www.eia.doe.gov/cabs/Egypt/ pdf.pdf, [22.01.2011]. 
As the data in the table above shows, the world economic crisis of 2008 and the continuous attacks by Somali pirates in the Horn of Africa and at the entry to the Red Sea, influenced the Suez Canal, which has highlighted the significant decrease of the way oil and petroleum is transported. There was also one more important fact in this case, the increase in exports of oil and petroleum from countries such as Algeria and Libya.

\section{POSSIBILITIES OF ALGERIAN PORTS ARZEW, SKIKDA AND BEJAIA IN THE CONTEXT OF ENERGY PRODUCTS EXPORT}

Algeria is a country of which $60 \%$ of the budget are receipts from the trade of raw energy materials, mainly from oil. 2009 Algeria produced 2.13 million b/d energy materials per day of which 1,33 was petroleum. Algeria is the fourth largest in Africa after Nigeria, Angola and Libya supplier of oil. As a member of OPEC it must obey prescribed limits by the Organization in the extraction of oil. In addition in 2008 Algeria was the sixth largest world supplier of gas just after Russia, the US, Canada, Iran and Norway.

As mentioned earlier, the daily oil extract in 2009 was 1.33 million b/d, which took place under the control of the national company Sonatrach. Sonatrach supports the largest accumulation of oil in Algeria Hassi Messaoud (around $26 \%$ of daily extraction) and Hassi Berkine, which is supported by the company Sonotrach and Anadarko (CA. 20\% of the daily extraction). In addition, all the time there are ongoing works on the exploration of new deposits of oil, which may replace the ending resources on existing beads. Sonatrach reported in December 2009 of the discovery of 16 new oil fields.

Algeria is a very important world exporter of crude oil. According to statistics, the EIA (Energy Information Administration) US companies imported in 2009488,000 b/d of Algerian fold, which placed the US in first place among the importers of Algerian oil and accounted for $27 \%$ of the total exports of the country. Similar quantities of barrels of oil were exported to the Europe countries $(482,000 \mathrm{~b} / \mathrm{d})$ of which: France, Germany, Italy, the United Kingdom were the man ones. 
Geografical strukture in Algerian's oil export in 2009

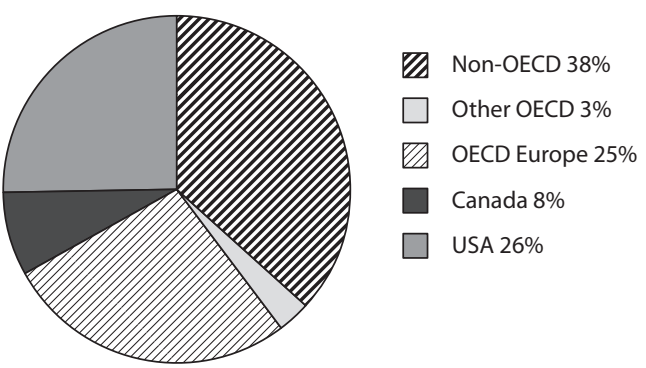

Fig. 3. Algeria’s oil exports, source: IEA, EIA, Retrieved 22.02.2011

Algeria has several significant petroleum processing refineries: Skikda - the largest refinery, with the possibility of processing 300,000 b/d, Hassi Massaoud - about 60,000 b/d and Arzew - about. 60,000 b/d. The planned construction of a new refinery in Tiaret is going to give the possibilities of reaching a capacity of $300,000 \mathrm{~b} / \mathrm{d}$, and is to be completed in 2013. All of these steps may increase the possibility to export raw materials, and thus become a competitive exporter for Persian Gulf oil especially for such customers as the United States and Western Europe ${ }^{24}$.

Constant export of Algeria's oil is provided by seven coastal export terminal, which are located in Arzew, Skikda, Annaba, Algiers, Oran, Bejaia and La Skhirra in Tenezji. Arzew as the largest terminal responsible for $40 \%$ of total exports of oil, Skikda supports about 15\% of exports of Algerian oil and Bajaia as the smallest terminal is responsible for $7 \%$ of exports.

Table 2. Export of Algerian oil form terminals, own analysis on the basis of: Algeria business page, http://www.algieriaonline.com/business/pages.php?cid=311, Retrieved 21.01.2011

\begin{tabular}{|l|c|c|c|}
\hline & 2007 & 2008 & 2009 \\
\hline Skikda b/d & 183,000 & 188,000 & 199,000 \\
\hline Arzew b/d & 488,000 & 500,000 & 532,000 \\
\hline
\end{tabular}

\footnotetext{
${ }^{24}$ Algeria, http://www.eia.doe.gov/cabs/Algeria/Background.html, [20.01.2011].
} 


\begin{tabular}{|l|c|c|c|}
\hline & 2007 & 2008 & 2009 \\
\hline Bejaia b/d & 90,000 & 87,570 & 93,100 \\
\hline Total export of oil in b/d & $1,219,000$ & $1,251,000$ & $1,330,000$ \\
\hline
\end{tabular}

Ensuring continuity of supply to the terminals is operated by Sonatach, that supports more than $3,200 \mathrm{~km}$ of oil pipelines across the country directly from the oil fields ${ }^{25}$.

As can be seen from this data, Algeria as the State of export of crude oil and petroleum to the countries of Western Europe and the US, which were not hit by the economic crisis, appeared in the fourth quarter of 2008 as drastically as Egypt. Security, continuity of supplies and their reliability is very important for the countries of the West, therefore after the riots in Tunisia and Egypt there are many concerns related to the situation, which may also be transferred to that country and may be the cause of international concern about the delivery of Algerian energy materials. The situation in North Africa is still very unstable and developing or even spreading to neighbouring countries.

\section{POSSIBILITIES OF ENERGY SECTOR IN LIBYA}

Libya has the most promising energy sector at the moment. Its rich resources of oil and gas, in a large part not yet exploited are attentiongrabbing for many companies dealing with, mining, processing and the transport of raw materials. After many years of the isolation of Libya in the international arena caused by a terrorist attack on an aircraft of the Pan Am airline, which collapsed on the Scottish town Lockerbie in 1988, with the death of the 270 victims, Libya decided finally to take full responsibility for that attack ${ }^{26}$. This has led to the warming of relations with this

25 Ibidem.

26 Two Libyan intelligence agents-Abdelbaseta Ali Mohmeda Al Megrahiego and Al Amin Khalifa Fhimaha were incriminated for this act, who organized this as a reaction to bombing of Tripoli and Benghazi on 14 April 1986 by Americans, during which Muammar al-Gaddafi had almost been killed. The refusal to hand over of the defendants to Scottish justice caused economic sanctions on Libya in 1992. Eventually, in 1999, Mua- 
country and the lifting of UN sanctions imposed after the attack. This warming has opened us new opportunities for Libya, to import advanced technologies which have given rise to the rapid development of the energy sector. This sector is the basis of the Libyan economy and a priority area of all investments. Within five years from 2003, production of crude oil increased by $25 \%$. The State shall establish $98 \%$ of export revenues, $90 \%$ of the revenues and 70\% of GDP. The table below presents the Libyan exports of crude oil over the last 3 years:

Table 3. Export of Libyan oil, source: OPEC Annual Statistical Bulletin 2008

\begin{tabular}{|l|c|c|c|}
\hline & 2007 & 2008 & 2009 \\
\hline Export of oil in b/d & $1.378 \mathrm{mln}$ & $1.404 \mathrm{mln}$ & $1.500 \mathrm{mln}$ \\
\hline
\end{tabular}

The energy sector related to the extraction, processing and transport of oil and gas has been controlled $100 \%$ by the State corporations Libyan National Oil Company (NOC) since 2000. It is responsible for issuing licences for the extraction of oil and gas, negotiating contracts, and the entire energy sector strategies in Libya. It also indirectly owns refineries in Zawia and Ras Lanuf. NOC (with the exception of its foreign partners) implements in Libya, $40 \%$ of the production of oil and $100 \%$ of the production of gas.

In addition, Libya has formed a joint venture dedicated to the extraction of gas and oil with other countries such as Egypt, Tunisia, Algeria and Pakistan. Libyan oil reserves are evaluated at 25.28 million barrels, NOC maintains optimistically that this might even be 117 million barrels. Despite the large disparities in assessment it is expected that the deposit are rich and are an absolutely essential element of the capital of Libya.

mmar al-Gaddafi issued the consent to extradition of assassinates. 16 August 2003, the Libyan Government signed a settlement and took responsibility for attack over Lockerbie and undertook to pay the family of each of the victims 10 million dollars. After that the UN sanctions were lifted. Tragedia $w$ Lockerbie, http://www.forum.spotter.pl/tragedia-lockerbie-1988-t1787/index.html?p=13740, [12.01.2011]. 
It is estimated that currently licensing on the extraction of oil is covered by only $25 \%$ of the overall resources, so it can be assumed that in the future maritime transport of oil from that country will grow as the demand for energy products in the world is constantly growing, so the prestige of Libya in the international arena can be significant. Transmission network for the transport needs of Libya consists of about $4,000 \mathrm{~km}$ of oil pipelines, which connects directly to the oil fields Sirte, Murzuk Ghadames with four full-time refiners and six maritime oil terminals on the Mediterranean Sea. The export of oil by tankers from Libya is implemented through the following Marine Petroleum terminals:

- Es-Sider-terminal for crude oil tankers, adopted up to 250,000 DWT;

- Marsa El Brega-terminal, refineries products, LNG and LPG, oil up to 300,000 DWT;

- Tobruk-terminal for crude oil tankers, adopted up to 120,000 DWT;

- Ras Lanuf terminal for crude oil and products of refineries, tankers up to 250,000 DWT;

- Zawia-terminal for crude oil and products of refineries, tankers up to 140,000 DWT;

Zueitina-terminal for crude oil tankers, adopted up to 270,000 DWT. The largest recipients of Libyan oil are now countries of the European Union. The geographical structure of exports of crude oil from Libya from 2008 was as follows:

Geographical structure of Libyan oil export b/d



Fig. 4. Libya's oil exports, source: Annual Statistical Bulletin 2008. OPEC. 
Among the European countries the largest recipients of Libyan oil in 2008 was: Italy (488,3 thousands b/d), Germany (207,8 thousands b/d), France $(139,4$ thousands b/d), Spain $(118,6$ thousands b/d), Switzerland (71.6 thousands b/d), United Kingdom (46,3 thousands b/d), Austria (18.3 thousands b/d), Netherlands (11.8 thousands b/d). The total volume of exports in 2008 by Libya amounted to 1.4 million $\mathrm{b} / \mathrm{d}^{27}$.

As the statistical data show European countries import more than one million barrels of oil and it is in their interest to keep a stable political situation in Libya as any potential problems in this part of the world may lead to destabilization of oil supplies and this would mean trouble for many European economies. At the end of February 2011 this situation was very dangerous because the people of Libya have demanded Muammar al-Gaddafi to resign. The country has been divided between supporters and opponents of the leader is in chaos and people die in the streets attacked by mercenaries. The international community is observing it and trying to work out the best reaction to the situation, which is really very dangerous for the whole international community. The UN Security Council unanimously ordered an arms embargo against Libya, a travel and assets ban on Moammar Gadhafi's regime and crimes against humanity investigation into the bloodshed on 26 February 2011.

\section{CONCLUSIONS}

Analysing the situation which has been taking place in North Africa should be underlined that it is Egypt that has the most influential impact on the region. The resignation of Hosni Mubarak opens a front of Egypt in two possible ways to follow in the future. The first one would be a comprehensible, in a sense of political systems, slow but permanent democratization of Egypt. Choosing this way the country can count on every possible help from democratic countries such as the US and the European Union (EU) as well as Israel, the nearest neighbour. This help would be

\footnotetext{
27 M. Kubicki, Sektor ropy naftowej i gazu w Libii, http://www.trypolis.polemb.net/ index.php?document=59, Ambasada RP w Trypolisie, [16.01.2011].
} 
very important as from our own experience such changes usually take some time and can be difficult for society.

The second way would be connected with gradual Islamisation of the country and stepping this way Egypt would get the total support from Islamic countries such as Saudi Arabia, Syria and Iran, which definitely would like to play the most important role in the region.

The Egyptian Army is going to play an essential part in the process of making decisions. The generals have taken over the rules at the moment and they are analysing the circumstances very carefully taking into consideration all internal and external factors. This process would probably last up to the scheduled election in Autumn this year. They will probably appoint their presidential candidate later in September and would support him. This might be the most important decision showing the international community which way Egypt will follow in the future, the democratic one or Islamic. Analyzing this over seven centuries it can be expected that young, educated Egyptians, who have won this uprising and forced Mubarak to resign, are going to chose the democratic way to build a modern and stable country. Their priority would be to give themselves a chance of a better life and future but the final decision will be taken during the elections to come.

The political situation in Tunisia and Egypt has been carefully observed by the international community but also by other neighbouring countries e.g. Algeria, Libya, Morocco, Qatar and Djibouti. The people of these countries would like to change their future as well. For this reason Egypt would be most likely a good example for them and the reaction in the countries may follow the domino pattern and make other regimes fall down and force changes of the political systems there. It cannot be sure that they would chose democracy because this system might not be the most appropriate for them because of their historical background. From the recent news it should be clear that the revolutionary movement in North Africa has not stopped yet and there is another country e.g. Libya fighting for their freedom from Muammar al-Gaddafi's regime.

The fall of regimes in Egypt and Tunisia have started geopolitical changes in the North Africa region. The US and the EU are very interested in a stable, predictable political situation in these countries as they are 
very important exporters or transit countries for energy products such as oil or petroleum. They are against strengthening Islamic fundamentalism in the region as this could result in the flourishing of terrorist organizations and anti Israeli trends in these countries. If this situation was to take place, Israel would be on the front line and Iran with Saudi Arabia would support Islamists. In the case of involving Israel, the US and EU would have to support them and involve their communities in this matter as it would absolutely change the security environment and endanger the whole international community. 